\title{
AN EXPERIMENTAL STUDY FOR PERFORMANCE AND EMISSIONS OF A SMALL FOUR-STROKE SI ENGINE FOR MODERN MOTORCYCLE
}

\author{
Khalaf I. Hamada ${ }^{1}$ and M.M. Rahman ${ }^{2,3}$ \\ ${ }^{1}$ Mechanical Engineering Department, College of Engineering, \\ University of Tikrit, Iraq \\ Email:dr_khalafih@tu.edu.iq \\ ${ }^{2}$ Faculty of Mechanical Engineering, University of Malaysia Pahang, \\ 26600 Pekan, Pahang, Malaysia \\ Eail: mustafizur@ump.edu.my \\ Phone: +6094246239; Fax: +6094246222 \\ ${ }^{3}$ Automotive Engineering Centre, University of Malaysia Pahang, \\ 26600 Pekan, Pahang, Malaysia
}

\begin{abstract}
The performance and emissions of a spark-ignited, port-injected, gasoline-fuelled, water-cooled, small-size modern motorcycle engine were investigated. For this purpose, an experimental test-rig was built up utilizing a small motorcycle engine for carrying out the practical tests. Experimental tests were performed for a range of engine speeds, various air-fuel ratios with a WOT condition and fixed timing of injection and ignition events. The experimental test-rig results consist of torque, power, brake mean effective pressure (bmep), AFR and emissions of the exhaust gas for various engine-dynamometer speeds. The accuracy of the test-rig measurement was verified by comparing both torque and brake power with benchmark data, which appear in the motorcycle technical manual. The acquired results indicated that conservation of the conventional mode of small engine characteristics is the distinctive impression for the tested engine. Further achievements are planned based on utilizing the developed test-rig and the attractive potential of a dual-fuel technique for reducing emissions and producing acceptable levels of torque and power.
\end{abstract}

Keywords: Port injection; modern motorcycle; small engine; gasoline-fuelled.

\section{INTRODUCTION}

The internal combustion engine (ICE) is the main technology employed for steering the transportation sector. The small size category of ICE is widely used as a convenient and compact source of power for various applications like motorcycles, scooters, etc. Challenges with ICE as their size is reduced include larger surface area to volume ratios that increase the heat loss and can lead to flame quenching [1-5] and also, as the size is reduced, residence times and turbulent mixing are reduced, leading to decreased combustion efficiency. Furthermore, as the size is reduced, the effect of leakage is exacerbated $[6,7]$. At the same time, this technology is associated with two issues that are threatening the whole world; the energy crisis and global warming. As a result, particular efforts are needed to boost engine performance and reduce emissions. It was observed that both of the fuelling methods have a crucial influence on the performance of ICEs. Fundamentally, most motorcycle engines used traditional carburettors [8]. 
However, this traditional system of fuel feeding does not provide flexible means to adjust the optimal conditions for engine operation. Therefore, new techniques have been proposed for robust fine-tuning of fuel quantities to boost engine performance and reduce emission levels. Electronically controlled fuel injection offer the prospect of realizing the fuel efficiency concept (giving the lowest fuel consumption and emissions) [9].Fuel injection allows the amount of fuel injected per cycle to be varied in response to inputs derived from sensors which define actual engine operating conditions [10]. The fuel injection system seems a promising technology as a means to supply suppressed fuel because of its high fuel delivery efficiency, enhanced fuel economy and reduced engine out emission [11-18].A fuel injector is a valve-nozzle combination that inserts a spray fuel into the air flow. The amount of injected fuel can be metered either by solenoid actuation (electronically controlled) or cam actuation (mechanically controlled) [19]. Spark ignition engines use fuel injectors to spray fuel into the air stream at the intake manifold (throttle body injection), inlet port (port fuel injection), or directly into the cylinder (direct injection) [20-22]. The advantages of port fuel injection over the carburettor are increased power and torque through improved volumetric efficiency and more uniform fuel distribution, more rapid engine response to changes in throttle position, and more precise control of the equivalence ratio during cold-start and engine warm-up [23]. Though the port fuel injection system has some advantages, it cannot at present meet the continuously increasing demands for performance, emission legislation and fuel economy [24]. So electronically controlled gasoline direct injection systems have started to be used instead of a port fuel injection system.

Direct injection is now becoming more commonplace in the automotive industry [25], as is established in the recreational 2-stroke engine product industry [12, 26, 27]. Direct injection can offer similar fuel economy, emission control and performance enhancement potential to a small 4-stroke engine as compared to the larger displacement automotive engines [28]. There are, however, specific challenges in applying direct injection to this application in comparison to the automotive application and these will probably preclude the current production of direct injection systems for motorcycles. They include [29]:

i) Packaging constraints of the DI systems,

ii) Smaller bore size and often higher maximum operating engine speed,

iii) System electrical current consumption considerations,

iv) Significant cost constraints (market-dependent),

v) System 'serviceability' and consideration of 'technology overload' for dealers and service people whose training, and tools, relate to the simple carburettor.

Moreover, in motorcycle engines, the layout of injection systems is subject to various potential limitations owing to the reasons that require the engine to be mounted in a narrow space [13].Therefore, the port fuel injection (PFI) system has been used widely in small four-stroke gasoline engines because of its advantages compared to the direct injection (DI) system based on [30]:

i) Low capital investment compared to GDI system;

ii) Best suited for 4-stroke engine;

iii) Mostly uses conventional components of an engine. 
Compared to car engines, motorcycle engines tend to have lower displacement volumes, and the need for high specific output power makes them operate at high revolution speeds. Due to the difference between motorcycle and automobile engines, it was uncertain whether the existing method of fuel injection had the potential to meet the response required for motorcycles. So for a motorcycle gasoline engine with a PFI system, it is vital to analyse and test the engine for assessment of the motorcycle's effectiveness. This can be implemented via measurements and correlation with real tests, which are especially important for perceptible performance and emissions.

This paper represents on-going research and emphasizes the evaluation of the characteristics of spark ignition engines operating with port injection on gasoline fuel alone. Miniature reciprocating ICEs have attractive potential for providing an energy source based on hydrocarbon fuel combustion for modern motorcycle applications. Hence, the purpose of this manuscript is essentially to investigate experimentally the performance and emissions of a modern small motorcycle engine. An experimental setup, as well as test procedures, were implemented for a certain motorbike engine. Through this robust experimental set-up and procedure, a diagnostic analysis of the performance and emissions of the tested engine using the port fuel injection approach can be achieved.

\section{EXPERIMENTAL DETAILS}

The experimental measurements for the present investigation were performed to complete the study in a logical manner. The main task in the current experimental work is to evaluate the performance and emissions of a small SI engine for motorcycle applications. A correctly setup engine and test cell with an appropriate data acquisition system are needed for acquiring precise and trustworthy data. The following sections give a detailed description of the engine, with its accessories; the test cell and dynamometer were utilized during experiments. A schematic of the experimental set-up with all details of the main components and connections is presented in Figure 1.

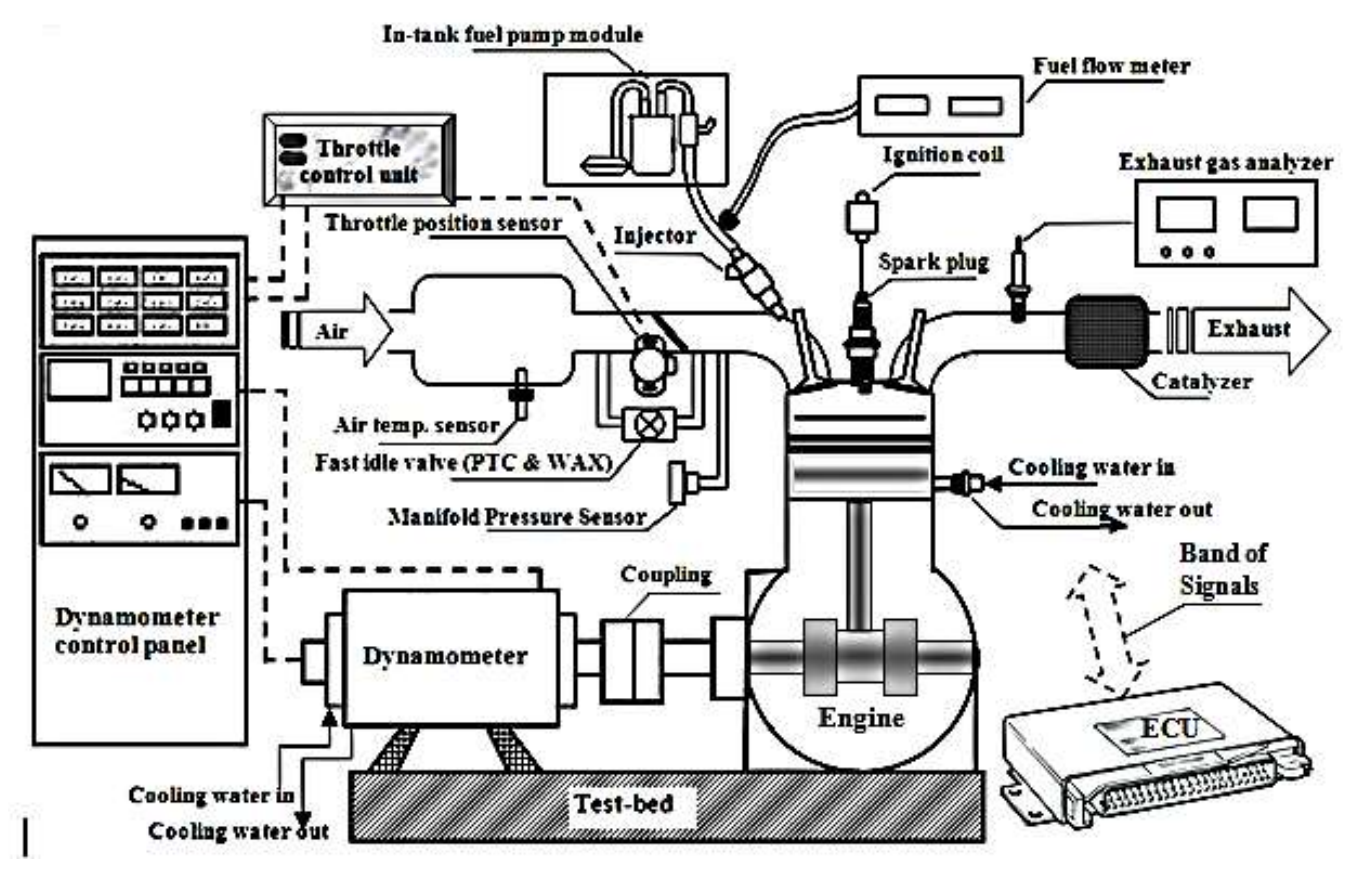

Figure 1. Schematic of the experimental set-up. 


\section{Engine Configuration}

The engine chosen for the current study was a single-cylinder, four-stroke, water-cooled spark ignition engine for Yamaha motorcycle model FZ150i. Since the engine is not available from the manufacturer as a stand-alone unit, a whole motorcycle was purchased from a private party. The parts that were not necessary for this research (rear wheel, drive belt, chassis, fender, and so on)were removed from the engine. The factory engine control unit (ECU) and wiring harnesses were kept attached to the test-rig. The engine control unit and wiring harnesses are a crucial part of the baseline measurement since they control the injection timing and ignition timing of the engine. The motorcycle vehicle and the test engine specifications are listed in Table 1. The original intake system of the tested engine is naturally aspirated and the mixture formation system is port injection in design. The aluminium cylinder head has a pent-roof configuration for the combustion chamber with a centre-mounted sparkplug. The cylinder head has dual intake and exhaust valves actuated by a single overhead cam (SOHV). Fuel is injected into the intake port by a single fuel injector located at the mid-point of the flow split. The injection system is composed of a low electrical current return type fuel pump, fuel pressure regulator, fuel filter, and injector. The fuel pump, fuel pressure regulator, fuel filter, and fuel level gauge are integrated into one compact form and are located inside the fuel tank so as not to interfere with other layouts. The fuel injector is 6-hole with a capacity of $125 \mathrm{~cm}^{3} / \mathrm{min}$ and an injection pressure of $250 \mathrm{kPa}$. The engine specification remains unchanged except for the cooling system, which has been modified to incorporate external and portable characteristics. The coolant temperature is controlled automatically based on the instantaneous cooling water outlet temperature. The temperature is measured using an adapted thermocouple and temperature scanner.

Table 1.Specifications of tested engine and motorcycle vehicle.

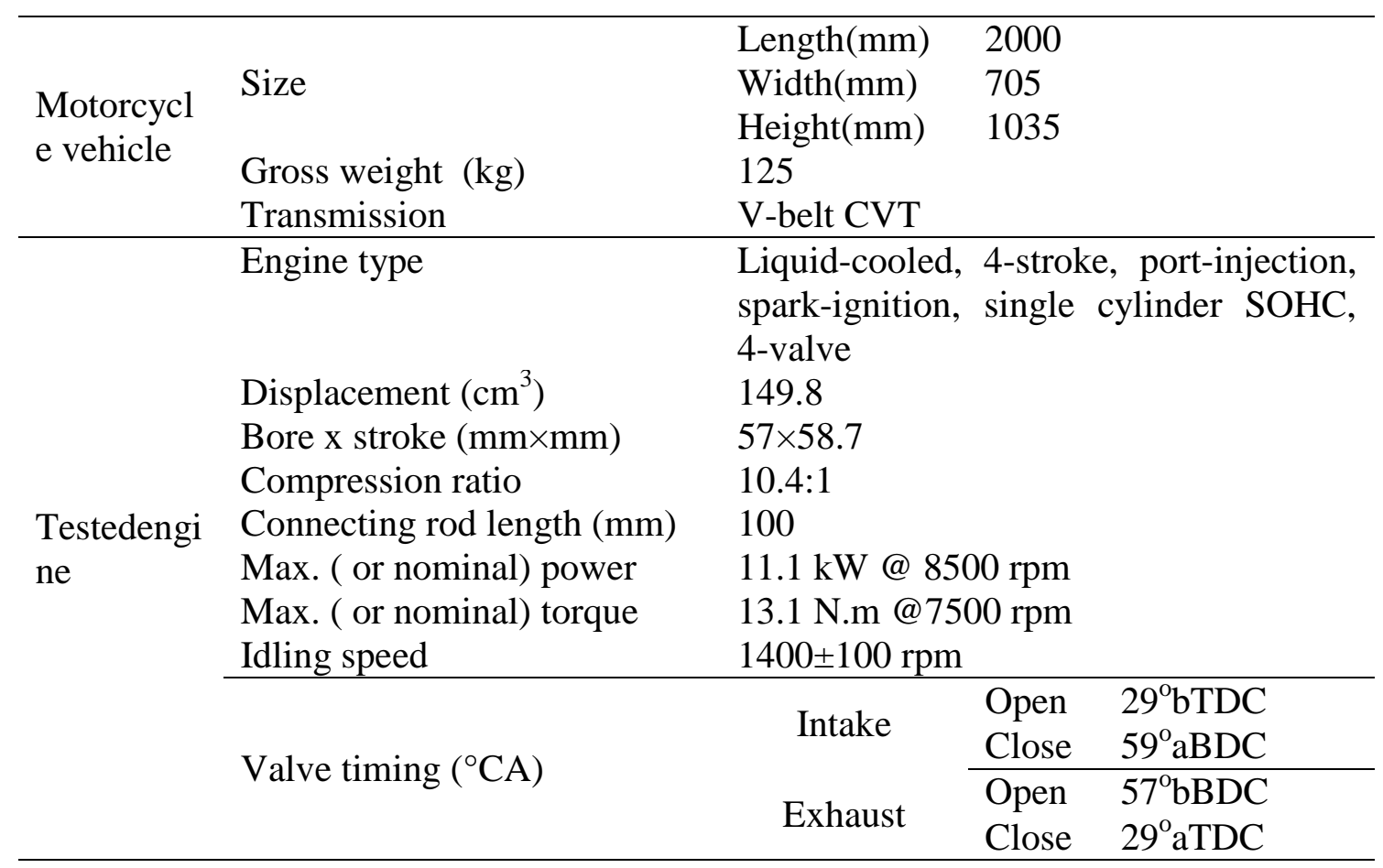


The base engine radiator was removed and engine coolant is taken directly to the external cooling system. An engine water pump circulates the coolant between the engine and the external cooling system, rather than an engine radiator. The external cooling system is made up of a three-way valve and a header tank heat exchanger. This three-way valve is actuated by a pneumatic actuator, which is used to govern the flow direction according to the temperature signal. The header tank is a shell and tube heat exchanger, with the engine coolant being the fluid flowing into the tube. The temperature of the coolant expelled from the engine is sensed by a thermocouple which transmits a signal to the temperature controller. The pre-set temperature specified for the controller was $70^{\circ} \mathrm{C}$ to match the manufacturer's settings. The rejected heat from the coolant in the header tank heat exchanger is carried by the water and rejected ultimately in a fan coil heat exchanger. The test engine was coupled to the dynamometer using the energy transmitting assembly(coupling) shown in Figure 1. This assembly utilizes a short propeller shaft guard with universal joints at each end. Connecting the propeller shaft guard to the engine's flywheel involved fabricating the adapter for mounting the universal joint on the engine side. A journal bearing was used to hold the fabricated adapter on the engine side. Use of this journal bearing ensures proper engine speed control from 800 to $10000 \mathrm{rpm}$, without oscillations arising from the enginedynamometer coupling natural frequency. On the dynamometer side, an adapter was fabricated to connect the propeller shaft guard with the dynamometer. Another journal bearing was used on the dynamometer side. The engine has a clutch which is used to engage the dynamometer for loading.

\section{Dynamometer}

The performance of reciprocating ICEs is usually measured using a dynamometer. A dynamometer is a device used to measure the torque and speed of a rotating machine operating in a controlled environment. It consists of a speed sensor, torque (force) sensor, and a controllable absorber and/or motor. A Dynalec Controls ECB-15 kW, eddy current, bi-directional, dry type dynamometer was utilized in this work for engine loading, power absorption and engine speed regulation. This dynamometer was selected based on matching between the values of the engine specifications (maximum torque and maximum power with corresponding engine speed values) and the dynamometer working envelopes (performance curves) which are given by the manufacturer as listed in Table 2. Table 2 lists the details of the dynamometer specifications. Engine torque is measured using a universal type, precision grade, load cell as a transducer attached to the lever armon the dynamometer shell. Dynamometer speed is measured using a noncontact type magnetic pulse pick-up sensor with $200 \mathrm{ohms}$ for coil impedance and $0.5 \sim 1$ $\mathrm{mm}$ for sensing distance. A 60-toothed gear wheel is mounted on the dynamometer shaft for displaying speed in rpm directly. Figure 1 shows the layout of the dynamometer coupled to the Yamaha test engine. The dynamometer electromechanically absorbs the power delivered by the engine. The heat generated by the applied torque is removed by utilizing a closed cooling circuit. The cooling circuit for the dynamometer is composed of an electrical centrifugal pump, cooling fan, pipes for connecting the cooling circuit and a special water reservoir filled with tap water. 
Table 2.Specifications of eddy current dynamometer.

\begin{tabular}{ll}
\hline \multicolumn{1}{c}{ Parameter } & \multicolumn{1}{c}{ Size and Feature } \\
\hline Type & Dynalec Control, model ECB-15 kW \\
Capacity & $60 \mathrm{~N} . \mathrm{m} @ 1500-2500 \mathrm{rpm} / 15 \mathrm{~kW} @ 2500-13000 \mathrm{rpm}$ \\
Max. excitation current & $6 \mathrm{amp}$ DC \\
Coil resistance & $12-15 \mathrm{ohms}$ \\
Coil to dynamometer & $500 \mathrm{M}$ ohms \\
Overall size & Width 510 mm and height 660 mm from plate form to \\
& centre of the shaft \\
\hline
\end{tabular}

\section{Throttle Control Unit}

Throttle control is one of the basic controls required for the testing of an engine. As the engine speed depends upon the throttle opening (position), to achieve stable engine speed, throttle has to be maintained at a particular position. All tests were performed under a wide open throttle condition. A Dynalec Controls TLPC/612A control unit and $\mathrm{TM} / 612 \mathrm{~B}$ throttle actuator were utilized in this work. To achieve stable operation of throttle at any particular position, because of its fast response and high holding torque action, a DC servo motor with a tuning belt and pulley arrangement is used for the throttle actuator. The throttle actuator is operated in a closed loop by taking position feedback. The throttle zero position and range of operation can be shifted electrically from the controller.

\section{Exhaust Gas Analyser}

The exhaust gas composition of the engine was analysed by the gas analyser kit. A portable KANE hand-held exhaust gas analyser was used to measure the concentration of the exhaust gas species. It is a compact design, fast warm-up, and it can be incorporated to measure $\mathrm{CO}(0-10 \%), \mathrm{CO}_{2}(0-16 \%), \mathrm{HC}(0-5000 \mathrm{ppm}), \mathrm{O}_{2}(0-21 \%)$, and $A F R$ (11.76-17.64). It is ideal for pre-compliance testing, vehicle diagnostics and servicing to the manufacturer's specification. It can be used for petrol/gasoline, LPG, CNG and diesel vehicles. A KANE analyser works on the principle of infrared spectroscopy measuring the concentration of each constituent $\left(\mathrm{CO}, \mathrm{CO}_{2}\right.$ and $\left.\mathrm{HC}\right)$. Oxygen and air-fuel ratio are measured using automotive electrochemical sensors. The exhaust stainless steel probe of the gas analyser kit was located in the exhaust manifold to sample the exhaust gas. A sampling system complete with a conveying line was attached to the probe to sample the exhaust gas. A hand-held display board was facilitated for the sampling process and logged the data.

\section{Test Procedure and Data Reduction}

The test engine was loaded with the help of an eddy current type dynamometer. Load applied to the engine was varied by using the knobs that change the excitation current in the stator of the eddy current dynamometer. The test procedure is based on the 'position-speed mode' test sequence [31]. In this mode, the throttle position continues to be set for a specified condition, but the dynamometer is equipped with an automatic controller, which adjusts the torque absorbed by the machine to maintain the engine speed constant whatever the throttle position and power output.This is a very stable 
mode and it is generally used for plotting engine torque-speed curves at full and part throttle opening. The throttle opening and engine speed are considered as independent variables. Currently, the throttle opening is controlled to achieve $100 \%$ opening, while the engine speed is set independently to satisfy the selected engine speed condition. The dynamometer load is then imposed to achieve the highest possible engine torque in that condition. Hence, other variables such as engine torque, power, and the emissions are considered as dependent variables. The data collection is carried out from $1800 \mathrm{rpm}$ to $3200 \mathrm{rpm}$ with an interval of $200 \mathrm{rpm}$ based on dynamometer speed. The engine test was repeated three times and arithmetical average value for each parameter was considered. To warm up the engine to the operating temperature, it is started on a very rich fuel-air mixture ratio. After the engine has been run for about 5 minutes on the rich setting, the mixture is leaned somewhat and the engine is again allowed to run for the same duration, then the data of interest data is recorded. Logically, the engine testing is intended to yield sufficient torque (exceed misfire limit) and avoid knocking noise. Accordingly, in this work the air-fuel ratio [32] parameter is optimized (through the ECU) to achieve the best brake torque with smooth operation for each tested point. The measurement of the $A F R$ was based on the exhaust gas analyser because it is more precise. The $A F R$ is dependent on the load and engine speed.

The brake torque, $T$, applied to the cradled housing was calculated by the moment arm connected to the balance weights [23]:

$$
T=F \times b
$$

where $T$ is brake torque in N.m, $F$ is applied load in N, and $b$ is the distance from the centre of the rotor in $\mathrm{m}$. Measurement of engine torque was carried out using a load cell attached to the dynamometer's arm. Calibration of the load sensor is carried out by employing a known load quantity to the load cell and comparing the given reading of the load cell to the theoretical value. Based on in-lab calibration, the load cell gives a maximum deviation of $2.33 \%$. In order to evaluate the trustworthiness of the measured results, the results must be compared in terms of more general and convenient parameters. These are enabled by deriving values for engine power, and bmep. These parameters are some of the parameters used for engine comparison [23, 33]. Moreover, for the current study, these parameters are compared against typical engine data for an SI engine.

The value of brake power was calculated based on the value of engine torque. The brake power, $P_{b}$, delivered by the engine and absorbed by the dynamometer is the product of torque and angular speed [34]:

$$
P_{b}=\frac{2 \pi \times N \times T}{60000}
$$

where $P_{b}$ brake power in $\mathrm{kW}$, and $N$ engine speed in rpm.

The engine output torque at the crankshaft, when related to the engine displacement, generates another performance parameter called bmep. This is a measure of work output from an engine and not of the pressure in the engine cylinder. Brake mean effective pressure is used to compare the performance of differing engine capacities and numbers of cylinders. It is measured in $\mathrm{kPa}$, and can be expressed as [35]: 


$$
\text { bmep }=\frac{P_{b} \times n_{r} \times 60}{2 \pi \times N \times V_{d}}
$$

where $n_{r}$ is the number of crank revolutions for one complete cycle, which is 2 for a four-stroke engine, and $V_{d}$ is the total volume of the engine cylinders in $\mathrm{m}^{3}$.

\section{RESULTS AND DISCUSSION}

The motorcycle with a 100-150 cc engine capacity is the most popular for personal transportation, especially in Asia. Finding ways to enhance the output torque, reduce the energy expenditure and eliminate the polluting emissions are always desired goals and ongoing challenges [36]. Therefore, the results of the current work are focused on the performance parameters and the exhaust pollutants aspects only under quasi steady state operation conditions. Injection timing variation has no effect on engine performance or emissions as long as the $A F R$ is held constant $[33,36]$. Therefore, the injection timing investigation was excluded here. The ignition and injection timing parameters are implicitly optimized (through the ECU) to achieve the maximum best torque. Measurements were carried out for the engine over a speed range from 6000 to 10700 rpm, which represents the road load conditions for motorcycle engines [29]. Recording of the engine speed was directly achieved and manually recorded from the speed indicator attached to the tested engine. However, it is difficult to perform engine tests with this range of engine speed. Therefore, it was reduced through a low transmission gear. The dynamometer speed was recorded from the dynamometer control panel. Figure 2 shows the variation of dynamometer speed against engine speed for the entire testing range. It reveals a linear relationship between the engine and dynamometer speeds with the $n$ slope equal to the ratio of the transmission gears.

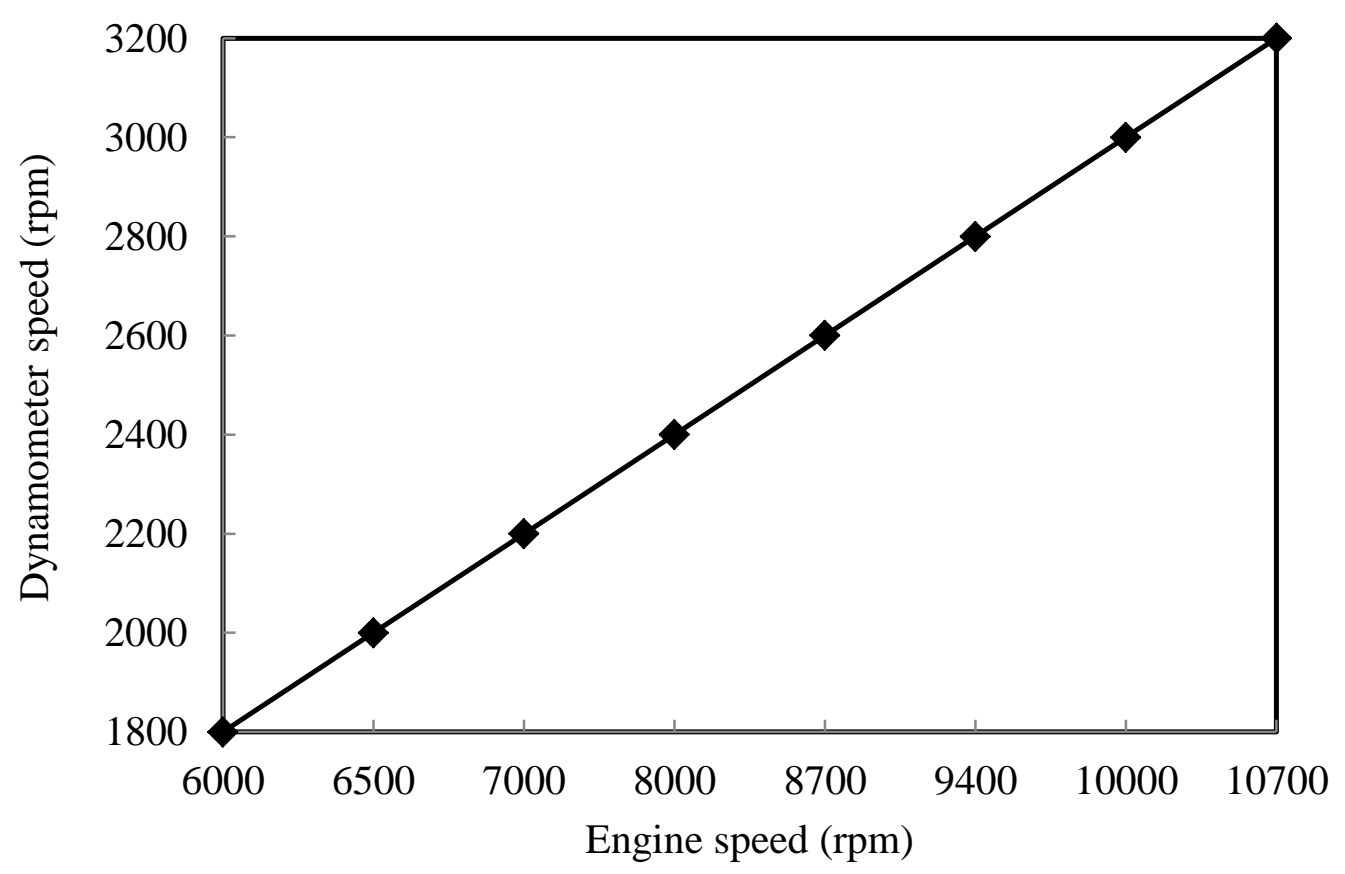

Figure 2. Variation of dynamometer speed versus engine speed. 


\section{Engine Performance}

The performance of the engine with respect to brake torque, brake power, and brake mean effective pressure was investigated for a wide range of engine speeds. However, all the following results will be presented with respect to dynamometer speed because it was the input variable during the experiments. Figure 3 shows the brake torque and brake power of the engine at WOT from 1800 to $3200 \mathrm{rpm}$ with $200 \mathrm{rpm}$ as a step change. It was found that the maximum brake torque and brake power obtained were 36.2 N.mand $10.84 \mathrm{~kW}$ at 2600 and 3000 rpmrespectively.However, it is clearly seen that both the highest torque and power are different and were achieved later than the rated values as given by the manufacturer's specification(see Table 1). This deviation is due to the highest reduction ratio of the engine transmission gear employed for all the experiments (see Figure 2). The typical trend of modern motorcycle engines is to produce a maximal curve of torque and power against engine speeds in which its maximum engine torque value is achieved at a lower engine speed than maximum power. At high engine speed, the engine cannot withstand the higher dynamometer load and thus the engine torque is reduced. This is because the increased friction in the engine components as the speed increases becomes dominant [19]. More work produced in the engine cylinder is used to overcome the increased friction. It can be noted that the results of the current experimental test rig coincide with this general trend.

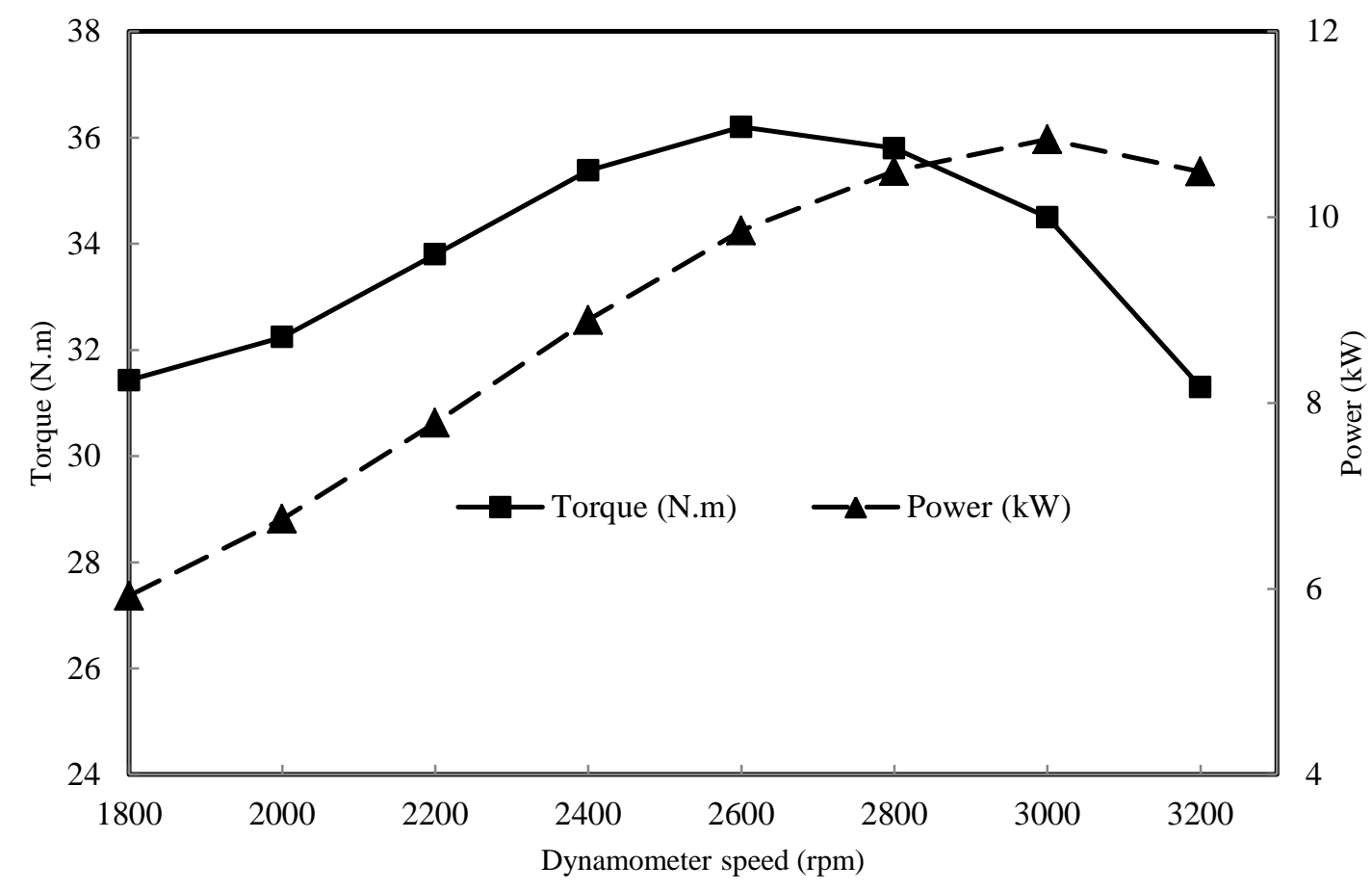

Figure 3. Variation of brake torque and brake power versus dynamometer speed.

Figure 4 presents variation of the brake mean effective pressure versus dynamometer speed for the WOT condition. The calculated bmep give values in the range of $395 \mathrm{kPa}$ at $10700 \mathrm{rpm}$ and $454 \mathrm{kPa}$ at $8700 \mathrm{rpm}$. Based on Heywood [23], the typical values of bmep for a natural aspirated small size spark-ignition gasoline engine are in the range of 400 at $4500 \mathrm{rpm}$ to $1000 \mathrm{kPa}$ at $7500 \mathrm{rpm}$. Thus, these results are 
considered as acceptable for the SI engine. Moreover, it can be seen that the bmep and brake torque trends show a small discrepancy with others.

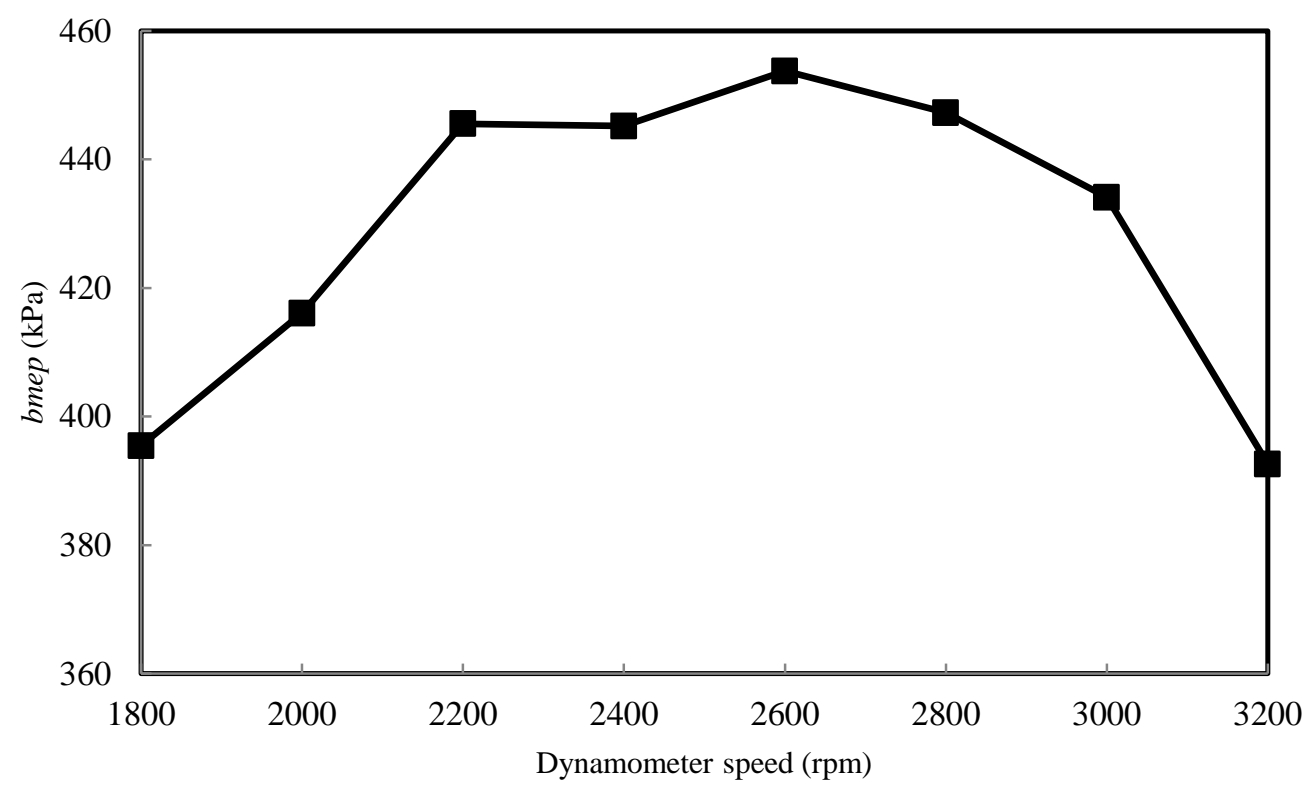

Figure 4. Variation of bmep versus dynamometer speed.

\section{Exhaust Pollutants}

The exhaust pollutants (emissions) of the engine, including carbon monoxide $(C O)$, carbon dioxide $\left(\mathrm{CO}_{2}\right)$, and unburned hydrocarbon $(\mathrm{HC})$, were investigated at various engine speeds. One of the most important variables affecting the emissions in the exhaust of the ICE is the AFR. Therefore, it is beneficial to assess the results of the engine emissions by presenting the behaviour of the $A F R$ prior to the production of these emissions. Figure 5 shows the variation of the $A F R$ and the volume fraction of $\mathrm{O}_{2}$ in exhaust gases versus dynamometer speed. It can be claimed that the port-injection gasoline engines' $A F R$ is optimised by the engine manufacturers, not controlled during this investigation. According to the graph, the $A F R$ is almost falling in the rich mixture region over the speed range for the tested engine (less than 14.5). The practical operating range of the $A F R$ for a naturally aspirated spark ignition engine is nearer to 9 to 25. In the current results, it is obvious that there is a significant drop of the $A F R$ beyond the speed of $1800 \mathrm{rpm}$. This is due to increase of the fuel flow as speed increases in order to maintain the highest engine power. The volume fraction of $\mathrm{O}_{2}$ has a coincident trend with the behaviour of the $A F R$ against dynamometer speed. This is expected because the $A F R$ is calculated from the relative concentrations of exhaust pollutants. Typically it is well-known that less $O_{2}$ denotes better combustion at the stoichiometric condition. It can be observed that beyond $1800 \mathrm{rpm}$, increasing engine speed decreases the $\mathrm{O}_{2}$ level due to better combustion.

Figure 6 shows the variation of the engine emissions versus dynamometer speed under the WOT condition. It can be observed that there are significant variations in the $\mathrm{CO}$ and $\mathrm{HC}$ but only slight variation for $\mathrm{CO}_{2}$. These behaviours are directly related to the variation of the $A F R$ versus dynamometer speed. The significant sources for $C O$ emission are the SI engines due to their running at stoichiometric or close to stoichiometric air-fuel ratios. 


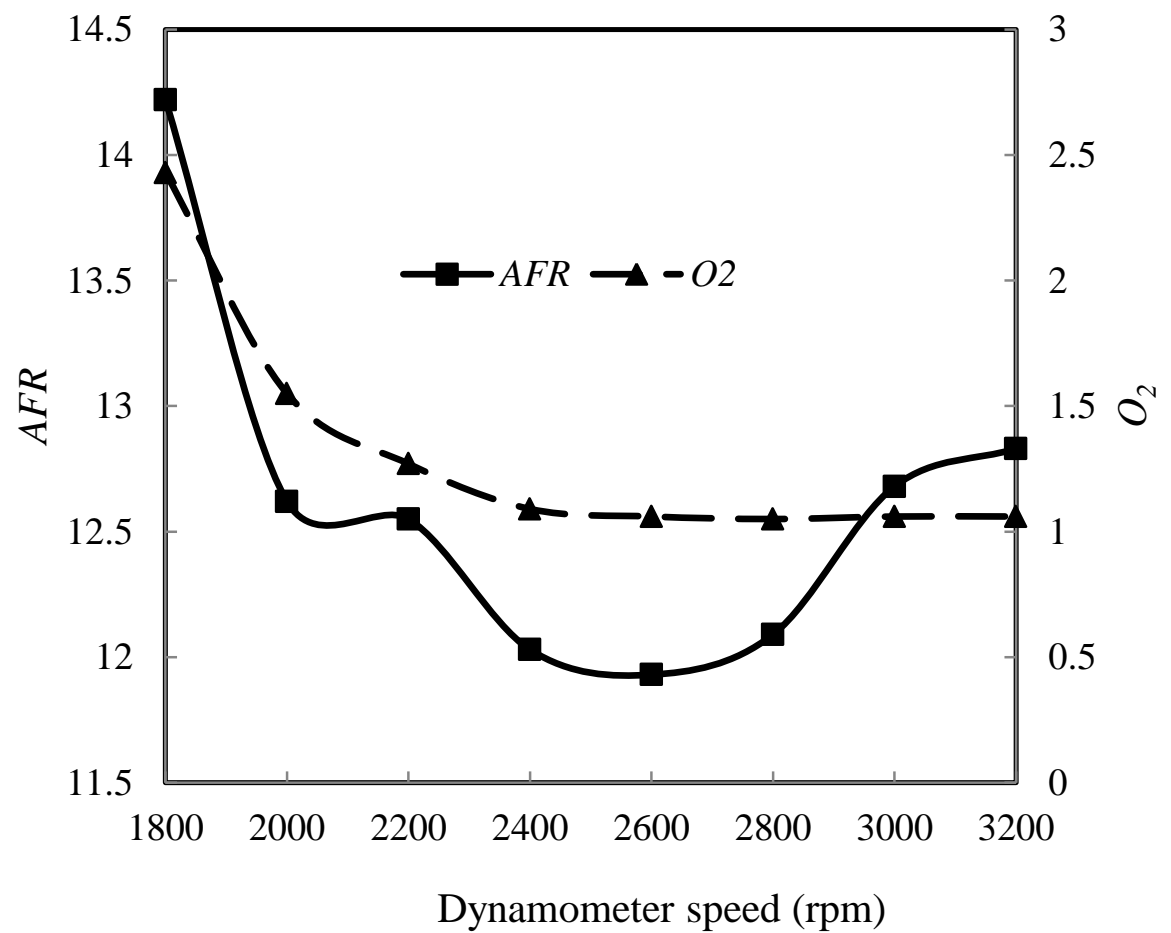

Figure 5.Variation of $A F R$ and $\mathrm{O}_{2}$ fraction versus dynamometer speed.

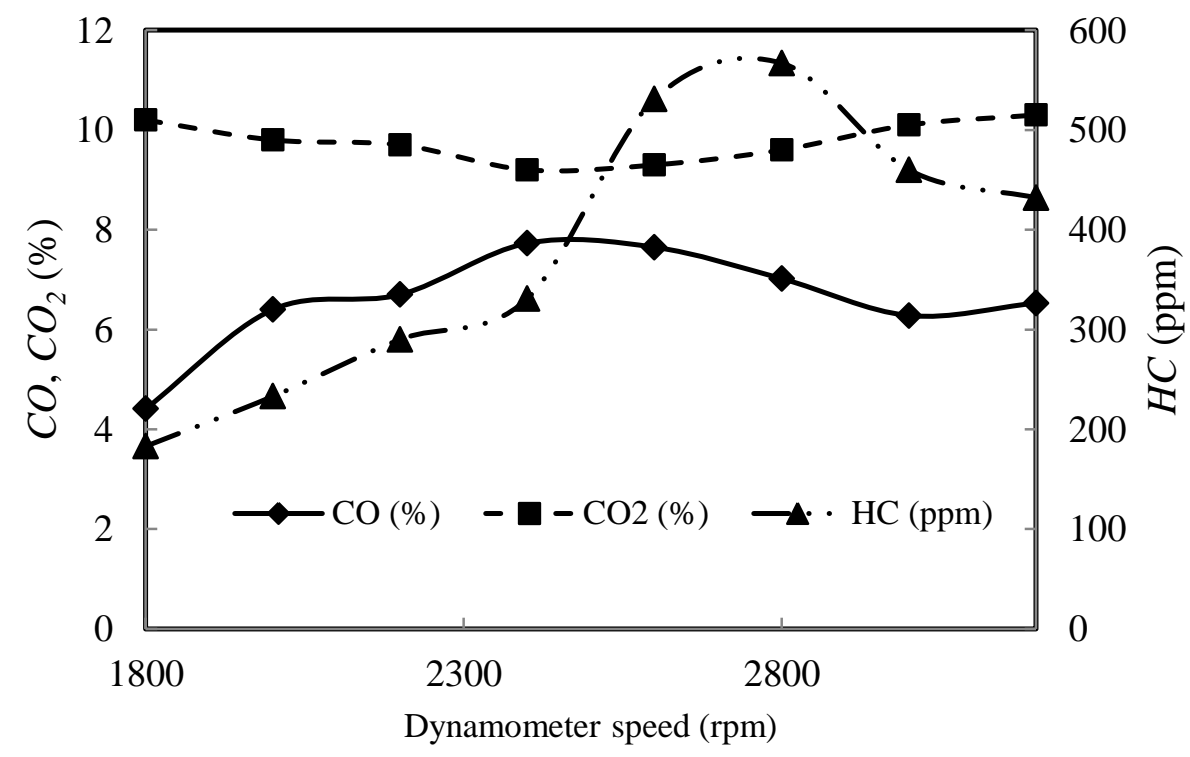

Figure 6. Variation of exhaust pollutants $\mathrm{CO}, \mathrm{CO}_{2}$ and $\mathrm{HC}$ versus dynamometer speed.

Basically, carbon monoxide $(\mathrm{CO})$ is produced through the combustion process with rich fuel-air mixtures. This is essentially because there is insufficient oxygen to fully burn all the carbon in the fuel to $\mathrm{CO}_{2}$. It is found that the volume fraction of $\mathrm{CO}$ produced is in the range of $4.41-7.73 \%$ over the engine speed range. Carbon dioxide is directly related to the combustion of fuel. Increasing $\mathrm{CO}_{2}$ means better fuel combustion. However, there is a limitation, as for gasoline fuel the maximum $\mathrm{CO}_{2}$ should be below $12.62 \%$ (this value comes from stoichiometric calculation) [37-39]. The volume fraction of produced $\mathrm{CO}_{2}$ is $9.775 \%$ on average over the whole engine speed range. This means that the tested engine was working in a very good condition. The $H C$ is mostly caused 
by an unburned fuel-air mixture, while the engine lubricant and incomplete combustion represent other sources. Similar to the $C O$ emission, one of the most important variables affecting the $H C$ emission in the exhaust is the air-fuel ratio. It is found that the concentration of $H C$ produced is in the range of $183-567 \mathrm{ppm}$ over the engine speed range. It is expected that the amount of unburned $H C$ decreases in the case of short combustion processes at high speeds. However, it is increased in Figure 6, as the dynamometer speed increases until $2800 \mathrm{rpm}$ then drops with further speed increment. This behaviour can only be interpreted by considering the variation of the $A F R$ versus dynamometer speed.

\section{CONCLUSIONS}

The data presented in this paper clearly reveals the prospective of the modern small engine for motorcycle applications. Implementation of an electronically-controlled portinjection for a gasoline engine as a base for a lightweight high-speed motorcycle was incredibly successful. Moreover, using the concept of a dual-fuel engine appears promising based on its potential for performance enhancement and emission reduction. Although the engine has not been developed with this concept yet, considerable progress in the structure of the engine test-rig and performance has been accomplished. The follow-on phase of the research agenda is incorporating the dual-fuel approach to realize the high performance and acceptable emission levels.

\section{ACKNOWLEDGMENTS}

The authors would like to thank Universiti Malaysia Pahang for financial support under project no. RDU110332 and Doctoral Scholarship scheme (GRS 090121).

\section{REFERENCES}

[1] Kamil M, Rahman MM, Bakar RA. Performance evaluation of external mixture formation strategy in hydrogen fueled engine. Journal of Mechanical Engineering and Sciences. 2011;1:87-98.

[2] Rahman MM, Noor MM, Kadirgama K, Rejab MRM. Study of air fuel ratio on engine performance of direct injection hydrogen fueled engine. European Journal of Scientific Research. 2009;34:506-13.

[3] Rahman MM, Mohammed MK, Bakar RA. Effects of air fuel ratio and injection timing on performance for four-cylinder direct injection hydrogen fueled engine. European Journal of Scientific Research. 2009;25:214-25.

[4] Hamada KI, Rahman MM, Aziz ARA. Influence of engine speed and mixture strength on instantaneous heat transfer for direct injection hydrogen fuelled engine. Energy Education Science and Technology Part A: Energy Science and Research. 2012;30:153-72.

[5] Hamada KI, Rahman MM, Abdullah MA, Bakar RA, A. Aziz AR. Effect of mixture strength and injection timing on combustion characteristics of a direct injection hydrogen-fueled engine. International Journal of Hydrogen Energy. 2013;38:3793-801.

[6] Ramasamy D, Yuan GC, Bakar RA, Zainal Z. Validation of road load characteristic of a sub-compact vehicle by engine operation. International Conference on Mechanical Engineering Research. 2013, p.1-3. 
[7] Sprague SB. Characterization of small-scale rotary engines and static combustion chambers. 2006.

[8] Lee FS, Tseng SC, Tsen CC, Wang JC. Fuel injection motorcycle engine model development. IEEE International Conference on Networking, Sensing and Control. 2004, p. 1259-64.

[9] Kato S, Hayashida T, Iida M. The Influence of port fuel injection on combustion stability. Yamaha Motor Technical Review; 2008.

[10] Yumoto $M$, Goto $K$, Kato S, Iida $M$. Influence of Injection and flame propagation on combustion in motorcycle engine-investigation by visualization technique. SAE Technical Paper NO. 2011-32-0566; 2011.

[11] Ramasamy D, Zamri M, Mahendran S, Vijayan S. Design optimization of air intake system (AIS) of $1.6 \mathrm{~L}$ engine by adding guide vane. Lecture Notes in Engineering and Computer Science. 2012; 1-6.

[12] Devarajan R, Samykano M. Evaluation of a two stroke compressed natural gas mixer design by simulation and experimental techniques. The 1st National Conference In Mechanical Engineering For Research \& Post Graduate Studies. 2010; 1-9.

[13] Hushim MF, Alimin AJ, Mansor MF. Effect of intake manifold angle of portfuel injection retrofit-kit to the performances of an SI engine. Applied Mechanics and Materials. 2012;165:31-7.

[14] Yusof MFM, Jamaludin N, Abdullah S, Hanafi ZH, Zain MSM. Monitoring and assessment of acoustic emission signatures during fatigue mechanism of API5LX70 gas pipeline steel. Journal of Mechanical Engineering and Sciences. 2012;2:237-50.

[15] Abdullah NR, Shahruddin NS, Mamat R, Ihsan Mamat AM, Zulkifli A. Effects of air intake pressure on the engine performance, fuel economy and exhaust emissions of a small gasoline engine. Journal of Mechanical Engineering and Sciences. 2014;6:949-58.

[16] Yusaf T, Baker P, Hamawand I, Noor MM. Effect of compressed natural gas mixing on the engine performance and emissions. International Journal of Automotive and Mechanical Engineering. 2013;8:1416-29.

[17] Sundar Raj C, Sendilvelan S. Effect of oxygenated hydrocarbon additives on exhaust emission of a diesel engine. International Journal of Automotive and Mechanical Engineering. 2010;2:144-56.

[18] Mohanamurugan S, Sendilvelan S. Emission and combustion characteristics of different fuel In A HCCI engine. International Journal of Automotive and Mechanical Engineering. 2011;3:279-92.

[19] Pulkrabek WW. Engineering fundamentals of the internal combustion engine: Singapore: Pearson New International Edition; 2003.

[20] Ferguson CR. Internal combustion engines, applied thermosciences. 2 ed. New York: John Wiley and Sons, Inc; 2001.

[21] Shamsudeen A, Abdullah S, Ariffin AK, Rasani MRM, Ali Y. Design and simulation of a cylinder head structure for a compressed natural gas direct injection engine. International Journal of Automotive and Mechanical Engineering. 2014;9:1620-9.

[22] Aziz A, Rashid A, Firmansyah, Shahzad R. Combustion analysis of a CNG direct injection spark ignition engine. International Journal of Automotive and Mechanical Engineering. 2010;2:157-70. 
[23] Heywood JB. Internal combustion engine fundamentals. New York: McgrawHill; 1988.

[24] Stone R. Introduction to internal combustion engines. UK: Palgrave Macmillan Limited; 2012.

[25] Shim YS, Choi GM, Kim DJ. Numerical and experimental study on hollow-cone fuel spray of highpressure swirl injector under high ambient pressure condition. Journal of Mechanical Science and Technology. 2008;22:320-9.

[26] Noor MM. Kadirgama K, Devarajan R, Sani MSM, Nawi MFM, Yusaf TF. CFD simulation and validation of the in-cylinder within a motored two stroke si engine. 2nd International Conference on Science and Technology, Applications in Industry and Education. 2008; 1461-1468.

[27] Ciccarelli G, Reynolds S, Oliver P. Development of a novel passive top-down uniflow scavenged two-stroke GDI engine. Experimental Thermal and Fluid Science. 2010;34:217-26.

[28] Drake M, Haworth D. Advanced gasoline engine development using optical diagnostics and numerical modeling. Proceedings of the Combustion Institute. 2007;31:99-124.

[29] Cathcart G, Houston R, Ahern S. The potential of gasoline direct injection for small displacement 4-stroke motorcycle applications. SAE Technical Paper; 2004.

[30] Hushim MF, Alimin AJ, Selamat H, Muslim MT. PFI System for retrofitting small 4-stroke gasoline engines. International Journal of Environmental Science and Development. 2013;4.

[31] Martyr AJ, Plint MA. Engine testing: The design, building, modification and use of powertrain test facilities. USA: Elsevier; 2012.

[32] Majid ZAA. Kajian prestasi sistem pengering pam haba terbantu suria dengan pengumpul suria multifungsi. Bangi, Malaysia: Universiti Kebangsaan Malaysia; 2011.

[33] Ramasamy D, Zainal Z, Bakar R, Kadirgama K. Mass fraction burn comparison of compressed natural gas and gasoline. Applied Mechanics and Materials. 2014; 660,442-6.

[34] Newbold D, Bonnick AW. A practical approach to motor vehicle engineering and maintenance. 2 ed. USA: Butterworth-Heinemann; 2005.

[35] Atkins RD. An Introduction to engine testing and development: SAE International; 2009.

[36] Shih C-J, Yeh C-N, Chang T-H. Experimental optimization and analysis of intake and exhaust pipeline for small engine motorcycle. Journal of Applied Science and Engineering. 2012;15:21г30.

[37] Ramasamy D, Aik Soon K, Walker-Gitano Briggs H, Zainal ZA. Variation of airflow pattern through dissimilar valve lift in a spark ignition engine. Journal of the Chinese Institute of Engineers, Transactions of the Chinese Institute of Engineers,Series A/Chung-kuo Kung Ch'eng Hsuch K'an. 2013;36:1083-96.

[38] Noor M, Kadirgama K, Devarajan R, Rejab M, Zuki N, Yusaf T. Development of a high pressure compressed natural gas mixer for a 1.5 litre CNG-diesel dual engine. Proceedings of the National Conference on Design and Concurrent Engineering (DECON) 2008. 2008:435-8.

[39] Kalam MA, Masjuki HH. An experimental investigation of high performance natural gas engine with direct injection. Energy. 2011;36:3563-71. 